\title{
The Analysis of Stock Price in Tourism Industry Listed in Indonesia Stock Exchange 2012-2016
}

\author{
Novita Kristiana Angela \\ anovitakristiana@gmail.com \\ Faculty of Business \\ Universitas Presiden, Cikarang, Indonesia \\ Yunita Ismail Masjud \\ yunitaismail@president.ac.id \\ Engineering Faculty, \\ Universitas Presiden, Cikarang, Indonesia
}

\begin{abstract}
The tourism industry showed rapid growth from year to year, but sales in some tourist companies were declined. This study was analyzed the stock price of tourism companies listed in Indonesia Stock Exchange from 2012-2016. There were PT Bukit Uluwatu Villa Tbk, PT Destinasi Tirta Nusantara Tbk, PT Jakarta International Hotels and Development Tbk, and PT Bayu Buana Tbk. This study conducted to prove the significant partially and simultaneously influenced of debt equity ratio $\left(\mathrm{X}_{1}\right)$, current ratio $\left(\mathrm{X}_{2}\right)$, earning per share $\left(\mathrm{X}_{3}\right)$, price to book value $\left(\mathrm{X}_{4}\right)$, and return on asset $\left(\mathrm{X}_{5}\right)$ towards the stock price $(\mathrm{Y})$. In addition, this research also identified the most significant influence factor towards the stock price. Data collection method was purposive sampling and got 80 observations from 4 companies in 5 consecutive years (2012-2016) which fulfilled the criteria. This research adopted quantitative research with multiple regression analysis. The result showed that from 5 independent variables, DER had negative significant to the stock price, CR had negative significant to the stock price, EPS positive significant to the stock price, PBV positive significant to the stock price, and ROA negative significant to the stock price. DER, CR, EPS, PBV, and ROA simultaneously had a significant relationship to the stock price. In summary, EPS and PBV is the variable that had the strongest influence to the stock price of tourism industry.
\end{abstract}

Keywords: Debt to Equity Ratio (DER), Current Ratio (CR), Earning per Share (EPS), Price to Book Value (PBV), and Return on Asset (ROA)

\begin{abstract}
Abstrak
Industri pariwisata menunjukkan pertumbuhan yang cepat dari tahun ke tahun, tetapi penjualan di beberapa perusahaan pariwisata menurun. Penelitian ini menganalisis harga saham perusahaan pariwisata yang terdaftar di Bursa Efek Indonesia dari tahun 2012-2016. Sampel yang digunakan adalah PT Bukit Uluwatu Villa Tbk, PT. Destinasi Tirta Nusantara, PT Jakarta International Hotels dan Development Tbk, dan PT Bayu Buana Tbk. Penelitian ini dilakukan untuk melihat dan menganalisis pengaruh secara signifikan secara parsial dan
\end{abstract}


simultan dari rasio hutang terhadap ekuitas (DER), asset lancar (CR), penghasilan per saham (EPS), harga sesuai nilai buku (PBV), dan rasio pendapatan terhadap aset (ROA) terhadap harga saham (Y). Selain itu, penelitian ini juga mengidentifikasi faktor yang berpengaruh paling besar terhadap harga saham. Metode pengumpulan data adalah data sekunder dan diperoleh 80 observasi yang memenuhi kriteria dari 4 perusahaan dalam 5 tahun berturut-turut (2012-2016). Penelitian ini merupakan penelitian kuantitatif dengan menggunakan analisis regresi berganda sebagai alat analisis datanya. Hasil penelitian menunjukkan bahwa dari 5 variabel independen, DER memiliki signifikan negatif terhadap harga saham, CR memiliki signifikan negatif terhadap harga saham, EPS positif signifikan terhadap harga saham, PBV positif signifikan terhadap harga saham, dan ROA negatif signifikan terhadap saham harga. DER, CR, EPS, PBV, dan ROA secara bersamaan memiliki hubungan yang signifikan dengan harga saham. Singkatnya, EPS dan PBV adalah variabel yang memiliki pengaruh besar terhadap harga saham industri pariwisata.

Kata Kunci: Rasio Hutang terhadap Ekuitas (DER), Asset Lancar (CR), Penghasilan per Saham (EPS), Harga sesuai Nilai Buku (PBV) dan Rasio Pendapatan terhadap Aset (ROA) terhadap Harga Saham (Y)

\section{INTRODUCTION}

Tourism industry become a very promising industry as evidence by the increasing number of foreign tourist arrival as seen in figure 1.

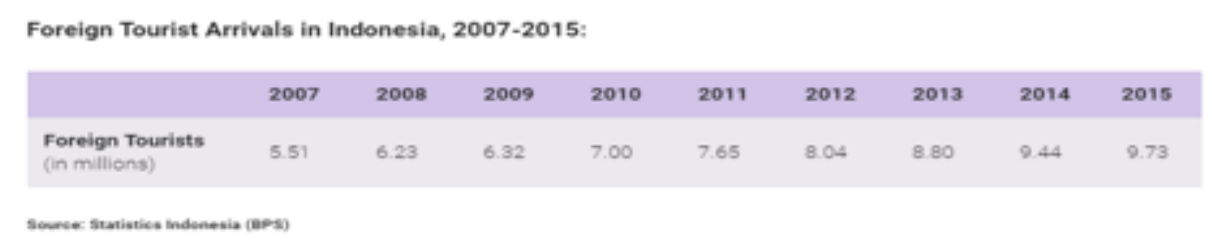

Figure 1: Foreign Tourist Arrivals From 2007-2015

According to the Figure 1, the number of foreign tourist arrivals in Indonesia has grown steadily from 2007-2015. This good performance supported by a devaluation in terrorist incidents in Indonesia. 
Table 1. Tourism Ranking Toward 11 Exports of the Largest Goods in 2015

\begin{tabular}{|c|c|c|}
\hline \multicolumn{3}{|c|}{2015} \\
\hline \multicolumn{2}{|c|}{ Commodities Category } & Value (million USD) \\
\hline \multicolumn{2}{|l|}{ Oil and Gas } & 18552,1 \\
\hline \multicolumn{2}{|l|}{ Coal } & 15943 \\
\hline \multicolumn{2}{|l|}{ Palm Oil } & 15385,2 \\
\hline \multicolumn{2}{|l|}{ Tourism } & 12225,89 \\
\hline \multicolumn{2}{|l|}{ Apparel } & 7371,9 \\
\hline \multicolumn{2}{|l|}{ Processed Foods } & 6456,3 \\
\hline \multicolumn{2}{|l|}{ Rubber Processed } & 5842 \\
\hline \multicolumn{2}{|l|}{ Electrical Appliance } & 5644,8 \\
\hline \multicolumn{2}{|l|}{ Textiles } & 4996 \\
\hline Wood Processed & 3815,8 & \\
\hline $\begin{array}{l}\text { Paper and Paper } \\
\text { products }\end{array}$ & 3605,5 & \\
\hline Chemical Material & 2807,6 & \\
\hline
\end{tabular}

Based on Table 1. in 2015 tourism industry ranked fourth. The difference can be seen from tourism to other categories below. The difference with palm oil was not too far from tourism industry. The difference only about 3159.31 million USD. This all because "Wonderful Indonesia" campaign's activity.

The tourism industry development, not showed by sales in some tourism companies. In this research, chosen four companies in tourism industry which were PT Bukit Uluwatu Villa Tbk, PT Jakarta International Hotel and Development Tbk, PT Bayu Buana Tbk, and PT Destinasi Tirta Nusantara Tbk (Panorama). The sales of that four companies showed at Figure 2. As a Figure 2, the stock price from four companies showed fluctuate from year to year.



Figure 2. Sales Four Tourism Companies from 2012-2016

Stock price could used to showed company healty. The fluctuation of stock price, could show that these companies not too stable in running business, or have the fluctuated condition. In this research, in seeing the fluctuated of stock price (dependent variable), some factors (variables) used, such as Debt Equity Ratio (DEB), Earning per Share (EPS), Current Ratio, Price of Book Value (PBV), Return on Asset (ROA) as a independent variables and Stock Price as a dependent variable.

Based on the explanation above, this study aims to answer the research questions as 
follow:

1. Is there any significant influence of debt equity ratio (DER) movement toward Stock Price?

2. Is there any significant influence of return on assets (ROA) movement toward Stock Price?

3. Is there any significant influence of Current Ratio movement toward Stock Price?

4. Is there any significant influence of EPS movement toward Stock Price?

5. Is there any significant influence of PBV (Price to Book Value) movement toward Stock Price?

6. Is there any simultaneous significant influence of DER, ROA, Current Ratio, EPS and PBV movement toward Stock Price?

\section{LITERATURE REVIEW}

Stock price were change everyday by market forces. Price fluctuation because of supply and demand. If more people want to buy a stock (demand) than sell it (supply), the price move up. Conversely, if more people wanted to sell a stock than buy it, there would be greater supply than demand, and price would fall. Understanding supply and demand is easy, but comprehend what makes people like a particular stock and dislike another stock. The principal theory about stock price is that the price movement of a stock indicates what investors feel a company is worth.

\section{The Effect of DER to the Stock Price}

Debt Equity Ratio is ratio that will used to determine debt with equity. Used to determine the amount of funds provided loans with the owner of the company (Kasmir, 2008). Debt equity ratio was factor that positive significant to the stock price. So that, as DER go increasing then the stock price of the company will increase also (Syafitri, 2016).

\section{The Effect of CR to the Stock Price}

According to Setiyawan (2014) current ratio had significant positive effect to stock price. Current ratio was ratio to determine the capability of company in paying its short-term obligation using its current assets. The bigger current ratio's value the higher the company's liquidity. Meaning, the level of high unemployment funds, which causes the company to lose the opportunity to take advantage of funds to improve the profitability of the company (Dewi, 2012). Based on the theory of rational expectations the greater the current ratio then the stock price will decrease because the company's performance is considered poor and investors will sell their shares.

\section{The Effect of ROA to the Stock Price}

Based on previous research Dimitropoulus (2009) stated that ROA had positive correlation to the stock price. As ROA increasing resulting in good impact towards company's value, this would bring positive response from the investors, so that demand for the shares of the company could growing up and increase the share price of the company.

\section{The Effect of PBV to the Stock Price}

According to Permana (2009) the greater the Price to Book Value, the better the growth of the company, so investors also find that the condition of the company will be profitable for investment. This, in turn will increase company's share price. The researcher found that PBV 
had an effect on stock price.

\section{The Effect of PS to the Stock Price}

Earnings per share was widely used as a tool of financial analysis (Irham, 2012). According to Sartono (2011) EPS ratio was the main benchmark of a company's success. Consistent profitability level would be a benchmark how the company to survive in business. According to Trisnawati (2012) found that EPS had positive impact to the stock price of hotel companies, tourism restaurant listed in Indonesia Stock Exchange.

\section{RESEARCH METHOD}

This research using secondary data that publish at Indonesia Stock Exchange from 2012 - 2016 for four tourism companies, which were PT Bukit Uluwatu Villa Tbk, PT Jakarta International Hotel and Development Tbk, PT Bayu Buana Tbk, and PT Destinasi Tirta Nusantara Tbk (Panorama). The data showed in quarterly financial report from that four companies and number of data were 80. Analyzing data used descriptive statistics and multiple regression for panel data with 4 independent variables and one dependent which was Stock Price.

The model in this research are:

$$
\text { Stock Price }=\alpha+\beta_{1} \text { DER }+\beta_{2} \text { CR }+\beta_{3} \text { EPS }+\beta_{4} \text { PBV }+\beta_{5} \mathrm{ROA}+e
$$

Hypothesis in this research were:

Hypothesis 1: There is significant influence of DER towards the stock price

Hypothesis 2: There is significant influence of CR towards the stock price

Hypothesis 3: There is significant influence of ROA towards the stock price

Hypothesis 4: There is significant influence of PBV towards the stock price

Hypothesis 5: There is significant influence of EPS towards the stock price

Hypothesis 6: There is significant simultaneous influence of DER, CR, ROA, PBV, and EPS to the stock price

The theoretical framework that used in this research showed at Figure 3.

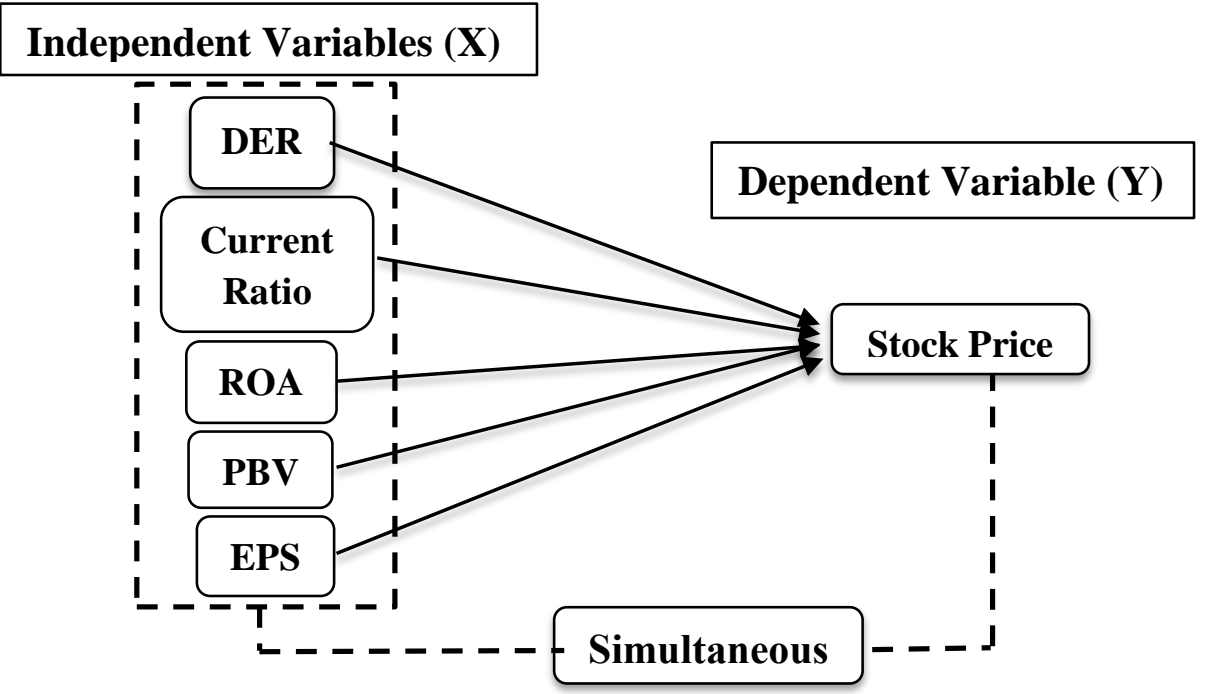

Figure 3. Theoretical Framework

Sources: (Satryo et al, 2016) 


\section{RESULTS AND DISCUSSION}

In this research descriptive statistics of the data show in Table 2.

Table 2. Descriptive Statistics

\begin{tabular}{|l|l|l|l|l|l|}
\hline VARIABLES & MEAN & MINIMUM & MAXIMUM & $\begin{array}{l}\text { STD. } \\
\text { DEVIATION }\end{array}$ & OBSERVATION \\
\hline Stock Price & 615.1774 & 130.3200 & 2100.000 & 434.4438 & 80 \\
\hline DER & 0.766762 & 0.266812 & 1.439142 & 0.297252 & 80 \\
\hline $\begin{array}{l}\text { CURRENT } \\
\text { RATIO }\end{array}$ & 1.501481 & 0.562809 & 4.857554 & 0.754466 & 80 \\
\hline EPS & 32.67526 & -28.53796 & 612.3202 & 97.82600 & 80 \\
\hline PBV & 1.008013 & 0.003626 & 2.458238 & 0.576082 & 80 \\
\hline ROA & 0.024404 & -0.015932 & 0.273785 & 0.044831 & 80 \\
\hline
\end{tabular}

Source: Process data

From Table 2, the standard deviation for variable stock price and EPS big enough compare with the mean. This two variable had big variation and showing the fluctuation value. Otherwise, from all data, there was no outlier, for that two variables too.

The regression model result by fixed effect method of this research were:

\section{Stock Price $=$ 244.1597 - 103.7123 DER - 46.62629 CR + 1.386106 EPS + 505.9245 PBV - 1422.758 ROA + e}

For this model classical assumption test result were:

1. Normality Test: the Jarque-Bera probability is 3.816157 , means the data is normally distributed.

2. Autocorrelation Test: the result of Durbin-Watson test shows the regression model has no tendency of the autocorrelation problem because the value of Durbin-Watson is 0.515357 that indicates those values are between -2 to +2 .

3. Multicollinearity Test: the highest value of matrix is 0.940650 which is the correlation between EPS and ROA because both of them is the part of profitability ratio. Which means that the multicollinearity problem is not tolerable when the value is more than 0.7. Hence, there is multicollinearity problem in this regression model.

4. Heteroscedasticity Test: it shows "white cross-section standard errors and covariance (d.f. corrected)". This method has function to solve the heteroscedasticity in the research. Thus, there is no heteroscedasticity problem in this research.

Using that model, the question in this research could answer by testing the hypothesis. For t-test, the p-value of DER was 0.0999, CR was 0.4269, EPS was 0.0013, PBV was 0.0001 , and ROA was 0.2001. Comparing with significance level, 0,05, it means EPS and PBV have significant influence to the stock price. For simultaneously test, using F-test, the probability is 0.000 , it means that the independent variables: DER, CR, EPS, PBV, and ROA have significant simultaneously effect to the stock price (dependent variable).

The Adjusted R square for the model was 0.762, it means the independent variables in this model (DER, CR, EPS, PBV, and ROA) could explain the dependent variable (stock price).

This study shows that DER has negative and no significant to the stock price. It can be seen from the coefficient on this variable of -103.7123 and the probability is 0.0999 . Since DER has negative impact to the stock price, it means that for 1 point increase of DER, it 
would decrease the value of Stock Price for about 103.7123. According to Trisnawati (2012) DER has negative impact to the stock price. The similar results were found by Ratih (2013) DER has negative impact to the stock price. Based on Ilham, et al (2015) also found that DER has negative impact to the stock price. According to the discussion above meaning that every investors has different opinion regarding to the debt aspects. But still the company that has debt will be better than the company that has debt.

This study shows that Current Ratio has negative impact and no significant to the stock price. It can be seen from the coefficient on this variable of -46.62629 and the profitability is 0.4269. Since CR has negative impact to the stock price, it means that for 1 point increase of CR, it would decrease the value of Stock Price for about 46.62629.

According to Dewi (2012) found that Current Ratio has negative impact to the stock price. The greater the CR value, the higher the level of company's liquidity. Meaning that the level of high unemployment funds, which causes the company to lose the opportunity to take advantage of funds to improve the profitability of the company. The similar results were found by Elizabeth (2016) CR has negative impact to the stock price. According to Michael (2008) also found that CR has negative impact to stock price. Current ratio shows the company's ability in paying the debt. It means that low or high CR value can't affect the stock price.

This study shows that EPS has positive and significant impact to the stock price. It can be seen from the coefficient on this variable of 1.386106 and the profitability is 0.0013 . Since EPS has positive impact to the stock price, it means that for 1 point increase of EPS, it would increase the value of Stock Price for about 1.386106.

According to Miftah and Fuadati (2012) found that EPS has positive significant to the stock price. Because EPS determine the company's net profit that is ready to be distributed to all shareholders of the company tends to increase, where the EPS is known from the financial statements presented by the company. EPS is an important indicator for consideration for shareholders. The similar result were found by Abimantrana (2014) EPS has positive significant to the stock price. According to Satryo, et al (2016) found that EPS has positive significant to the stock price. The other researcher also found EPS has positive significant to the stock price based on Hermawanti and Hidayat (2016).

This study shows that PBV has positive and significant impact to the stock price. It can be seen from the coefficient on this variable of 505.9245 and the profitability is 0.0001 . Since PBV has positive impact to the stock price, it means that for 1 point increase of PBV, it would increase the value of Stock Price for about 505.9245.

The other researcher found that PBV has positive significant to the stock price according to Sitio (2012). The similar result were found by Devi (2014) PBV has positive significant to the stock price. According to Aras and Yilmaz (2008) PBV can be used to consider index of market return. Based on Marlina (2013) found that PBV has positive significant to the stock price. Previous research from Hidayati (2010) also found that PBV has positive significant to the stock price. PBV has positive significant to the stock price Suriany (2013). Meaning that this ratio measures the value that financial markets give to management and organization as a growing company.

This study shows that ROA has negative and no significant impact to the stock price. It can be seen from the coefficient on this variable of -1422.758 and the profitability is 0.2001 . Since ROA has negative impact to the stock price, it means that for 1 point increase of ROA, it would decrease the value of Stock Price for about 1422.758 .

The previous research found that ROA has negative impact to the stock price according to Satryo, et al (2016). Based on Ilham, et al (2015) found that ROA has negative impact to the stock price. According to Darnita (2012) found that ROA has negative effect to the stock 
price. It can be concluded that ROA only measures the company's ability to generate net income based on certain level of assets. So, ROA has no effect to the stock price.

From model, EPS and PBV gave a significance effect to stock price, but DER, CR and ROA do not gave a significance effect. The two factors, EPS and PBV gave positive effect. The important factor that affects the value of a company is its earning. Earning are the profit a company makes, and in the long run no company can survive without them.

\section{CONCLUSION}

Based on the research about the influence of debt, liquidity, market, and profitability to the stock price on tourism companies, the conclusion can be sum up as follows:

1. DER movement has no significant influence to the Stock Price

This is because each investor has different perception on the debt aspect. But still the company that has no debt will be better than the company that has debt. Such good performance can benefit the companies.

2. Current Ratio movement has no significant influence to the Stock Price

Current Ratio is one of common ratio used to measure liquidity or the company's capability to pay the short-term without facing difficulty. Means low or high CR value can't affect to the stock price.

3. EPS movement has positive significant influence to the stock price

EPS showed the profitability of the company obtained on each sheet shares. The higher the value of EPS, of course, encourages the shareholders because of the greater profits provided to shareholders and the possible increase in the amounts of dividend received by shareholders.

4. PBV movement has positive significant influence to the Stock Price

Price to Book Value is one way to measure the value of the stock either cheap or expensive. The ratio of a stock's market price to its book value gives an indication of an investor's view of the company. This ratio measures the value that financial markets give to management and organization as a growing company.

5. ROA movement has no significant influence to the Stock Price

Based on the theoretical review ROA measures the company's ability to generate net income based on certain level of assets. Which proves ROA has no effect to the stock price.

6. There is significant simultaneous influence of DER, CR, EPS, PBV, and ROA movement on the Stock Price.

This means that DER, CR, EPS, PBV, and ROA at the same time give an effect to the Stock Price.

Recommendation from this research are:

1. For tourism companies, as a risk taker, consider to increase the EPS as one of the key performance on measuring the stock price.

2. For investors, are prompted to do observation and analyze DER, CR, EPS, PBV, and ROA of the tourism companies. Investors are also suggested to look in detail to the other financial ratios of the companies which can help analysis of the stock price performance of tourism companies.

3. For other researcher, need to provide more information to fill an importance gap in understanding the determinants of the stock price performance that will affect the tourism companies in Indonesia. 


\section{REFERENCES}

Abimantrana, A.P. (2014). The Influence of Financial Performance on Stock Price around Publication Date of Financial Statements: A Study in Food and Beverages Companies on BEI. Jurnal Ilmiah Mahasiswa FEB, 2(2).

Anita \& Yadav, P. (2014). Influence of Selected Financial Indicators on Stock Price of Tata Motors Ltd. International Journal of Application or Innovation in Engineering and Management, 3(7). ISSN 2319-4847.

Chittoo, H.B., Odit, M, P. (2008). Does Financial Leverage Influence Investment Decisions? The Case of Mauritians Firms. Journal of Business Case Studies, 4(9), 49-60.

Damar, et.al. (2015). Analysis of The Effect of Financial Leverage and Liquidity Towards Stock Value and Profitability As The Intervening Variable in Trading Companies Listed at Indonesia Stock Exchange 2010-2014. Journal of Business Studies, 109-116. ISSN 2461-0704.

Darnita, Elis. (2012). Analisis Pengaruh ROA, Return on Equity, Net profit Margin, dan Earning per Share Terhadap Harga Saham: Studi pada Perusahaan Food and Beverages yang terdaftar di BEI pada tahun 2008-2012, 1-16.

Devi, I.N. (2014). Pengaruh PBV, EPS, dan DER Terhadap Harga Saham Dengan Kebijakan Dividend Sebagai Variable Intervening: Studi Pada Perusahaan Manufaktur Yang Terdaftar di BEI Tahun 2009-2013. Universitas Brawijaya. Malang

Dewi, R., Wahyudi, S. (2012). Analisis Pengaruh Rasio Keuangan dan Makro Ekonomi Terhadap Harga Saham pada Perusahaan LQ 45 Index yang Terdaftar di BEI tahun 2007-2011. Diponegoro Journal of Management, 1(1), 1-11.

Dimitropoulos, P., and D. Asteriou. (2009). The Value Relevance of Financial Statements and Their Impact on Stock Price Evidence from Greece. Managerial Auditing Journal. 24(3), 248-265.

Elizabeth, S.M. (2016). Analisis Pengaruh Faktor Fundamental Terhadap Harga Saham dengan ROA Sebagai Variabel Intervening Pada Saham Sektor Pertambangan di Bursa Efek Indonesia Periode 2013-2015. STIE MDP. Palembang.

Ginting, S., \& Suriany. (2013). Analisis Faktor-Faktor yang Mempengaruhi Harga Saham Pada Perusahaan Manufaktur di Bursa Efek Indonesia. Jurnal Wira Ekonomi Mikroskil, $3(2)$.

Guler, Aras., and Mustafa Kemal Yilmaz. (2008). PER, Dividend Yield, and Market to Book Ratio to Predict Return on Stock Market: Evidence from the Emerging Markets. Journal of Global Business and Technology, 4(1).

Hermawanti, P., \& Hidayat, W. (2016). Pengaruh Earning Per Share, Price Earning Ratio, Debt to Equity Ratio, Return On Asset, dan Return on Equity Terhadap Harga Saham: Studi Kasus Perusahaan Go Public Sektor Property dan Real Estate. Jurnal Ilmu Administrasi Bisnis, 5(3).

Hidayati, E,E. (2010). Analisis Pengaruh DER, DPR, ROE, dan Size Terhadap PBV Perusahaan Manufaktur yang Listing di BEI periode 2005-2007. Universitas Diponegoro.

Ilham, et.al. (2015). Pengaruh Kinerja Keuangan Terhadap Harga Saham Pada Perusahaan Hotel, Restoran Pariwisata Yang Terdaftar di BEI Tahun 2011-2014, 9(2).

Marlina, T. (2013). Pengaruh Earning Per Share, Return on Equity, Debt to Equity Ratio dan Size Terhadap Price to Book Value. Jurnal Ilmiah Akuntansi dan Kesatuan, 1(1). ISSN 2337-7852. STIE Kesatuan. Bogor.

Mifta, M.S., \& Fuadati, S, R. (2012). Pengaruh Current Ratio, Debt to Equity Ratio, Return on Equity, dan Earning Per Share Terhadap Harga Saham Perusahaan Semen yang Terdaftar di Bursa Efek Indonesia. Jurnal Ilmu dan Riset Manajemen, 1(2). 
Muksal (2016). Analisis Faktor-Faktor yang Mempengaruhi Harga Saham Syariah: Studi Pada Pasar Sekunder Jakarta Islamic Index. Research Gate.

Permana, Y. (2009). Pengaruh Fundamental Keuangan, Tingkat Bunga dan Tingkat Inflasi terhadap Pergerakan Harga Saham. Jurnal Ilmiah Mahasiswa, 1-6.

Ratih, Dorothea. (2013). Pengaruh Earning Per Share, Price earnings Ratio, Debt to Equity Ratio, dan Return on Equity Terhadap Harga Saham Pada Perusahaan Sektor Pertambangan yang Terdaftar di BEI tahun 2010-2012. Diponegoro Journal of Social and Politic tahun 2013, 1-12.

Riantani, S., et.al. (2011). Analysis of Debt To Equity Ratio and Return On Asset and its Effect to Closing Price of the Mining Industry Listed in BEI. ACSSR2011.

Satryo, A,G., et.al. (2016). The Influence of Profitability Ratio, Market Ratio, and Solvency Ratio on the Share Price of Companies Listed on LQ 45 Index. The Indonesian Accounting Review, 6(1), 55-66. DOI 10.14414.

Setiyawan, Indra. (2014). Pengaruh Current Ratio, Inventory Turnover, Time Interest earned dan Return on Equity terhadap Harga Saham pada Perusahaan Manufaktur Sektor Barang Konsumsi yang terdaftar di BEI Periode 2009-2012. Jurnal Nominal, 3(2), 1-17.

Sitio, Daniel. (2013). Pengaruh Variabel Fundamental terhadap Harga Saham pada Perusahaan Hotel dan Pariwisata di BEI. Jurnal Administrasi Bisnis, 1(2). Universitas Brawijiya.

Syafitri, Y., \& Tamba, S.A. (2017). Pengaruh Kinerja Keuangan Terhadap Harga Saham Pada Perusahaan Industri Farmasi yang Terdaftar di BEI 2013-2015. Jurnal Kompetitif, 6(1).

Trisnawati, Mamik. (2012). Pengaruh Current Ratio, Debt to Equity Ratio, Return on Equity, Net Profit Margin dan Earning Per Share Terhadap Harga Saham Studi Kasus Perusahaan Food and Beverages yang Terdaftar di BEI 2009-2012. 1-18. Universitas Dian Nuswantoro: Semarang. 